PAY Jurnal Keuangan dan Perbankan. Vol. 3 No. 1, Juni 2021

\title{
ANALISIS RISIKO PEMBIAYAAN MUDHARABAH DAN MUSYARAKAH PERBANKAN SYARIAH PADA PT. BANK BRI SYARIAH TBK. YANG TERDAFTAR DI BURSA EFEK INDONESIA (BEI)
}

\author{
Sudirman Sappara \\ Fakultas Ekonomi dan Bisnis Universitas Muslim Maros \\ sudirmansappara@umma.ac.id
}

\begin{abstract}
ABSTRAK
Penelitian ini bertujuan untuk mengetahui tingkat risiko pembiayaan mudharabah dan musyarakah Perbankan Syariah pada PT. Bank BRI Syariah Tbk. Periode tahun 2015 sampai 2019.

Metode analisis yang digunakan dalam penelitian ini adalah metode Rasio NPF (tingkat risiko pembiayaan). Data yang digunakan adalah laporan keuangan tahunan dari tahun 2015 sampai 2019. Untuk mengelola dan menganalisis data yang diperoleh serta membuat kesimpulan.

Berdasarkan hasil analisis data diperoleh hasil penelitian ini adalah tingkat risiko pembiayaan (NPF) mudharabah PT. Bank BRI Syariah, Tbk pada tahun 2015 sampai 2019 berada kondisi yang baik atau tidak berisiko atau berada diperingkat pertama $<2 \%$. sedangka tingkat risiko pembiayaan mudharabah dari tahun 2015 sampai 2019 paling tinggi terjadi pada tahu 2018 sebesar 1.38\%. Dan tingkat risiko pembiayaan (NPF) musyarakah PT. Bank BRI Syariah, Tbk pada tahun 2015 sampai 2018 berada dalam kondisi berisiko atau berada di peringkat ketiga 5\% $\leq \mathrm{NPF}<8 \%$. Pada tahun 2019 tingkat risiko pembiayaan musyarakah berada dalam kondisi yang baik atau berada diperingkat kedua $2 \% \leq \mathrm{NPF}<5 \%$. Sedangkan tingkat risiko pembiayaan musyarakah dari tahun 2015 sampai 2019 paling tinggi terjadi pada tahu 2018 sebesar $7.89 \%$.
\end{abstract}

Kata Kunci: Pembiayaan Mudharabah dan Pembiayaan Musyarakah

\section{PENDAHULUAN}

\section{A. Latar Belakang}

Bank merupakan usaha yang bergerak dalam bidang keuangan artinya usaha perbankan selalu berkaitan dengan masalah bidang keuangan. Jenis-jenis bank terbagi menjadi dua, yaitu Bank Konvensional dan Bank Syariah, dimana, Bank Kovensional berfungsi mengumpulkan dana dari masyarakat dan menyalurkan kembali dana tersebut kepada masyarakat sedangkan bank syariah berfungsi sebagai lembaga yang melaksanakan kegiatan operasionalnya dengan menghimpun dana dari masyarakat dan kemudian meyalurkannya kembali kepada masyarakat dalam bentuk pembiayaan dan berdasarkan prinsip-prinsip syariat Islam. Berbicara mengenai kemunculan Bank yang berbasis syariah di Indonesia sendiri, muncul pada tahun 1991. Bermulah disitulah lambat laun perkembangan lembaga keuangan ekonomi Islam di Indonesia mulai berkembang dengan baik sampai sekarang. Persaingan antara Bank Syariah yang semakin ketat seiring berkembangnya zaman. Meskipun Bank syariah memiliki motivasi lebih dari ada sekedar bisnis, kemampuan Bank syariah dalam menghasilkan keuntungan menjadi indikator penting untuk mengukur kemampuan bersaing Bank Syariah dalam jangka panjang dan dapat 


\section{PAY Jurnal Keuangan dan Perbankan. Vol. 3 No. 1, Juni 2021}

dilihat juga bank syariah di Indonesia dalam rentang waktu yang relatif singkat telah memperlihatkan eksistensinya dalam sistem perekonomian nasional.

Indonesia yang merupakan Negara dengan jumlah penduduk Muslim terbesar di dunia menjadikan perkembangan perbankan syariah memiliki peluang besar. Perkembangan ini dapat kita lihat semakin banyaknya perbankan syariah di Indonesia. Karena, masyarakat Muslim di Indonesia mulai sadar akan pentingnya memilih menabung dan menggunakan jasa perbankan syariah karena menggunakan sistem bagi hasil bukan bunga/riba. Hal ini dapat di lihat dari peran masyarakat dalam menggunakan produk-produk perbankan syariah salah satunya produk penyaluran dana pembiayaan. Bentuk pembiayaan Bank syariah terdiri dari 7 bentuk pembiayaan diantaranya adalah pembiayaan murabahah, mudharabah, musyarakah, salam, ijarah, qardh dan isthisna (Menurut: Muhammad Yusuf dan Wiroso (2011).

Memberikan pembiayaan atau Penyaluran dana kepada calon nasabah bank harus benar-benar teliti dan selektif, bank harus melakukan penilaian terlebih dahulu terhadap pembiayaan yang akan disalurkan ke calon nasabah yang mengajukan pembiayaan. Hal tersebut perlu dilakukan oleh pihak bank agar tidak terjadi hal-hal yang menimbulkan kerugian seperti halnya nasabah tersebut tidak mampu membayar kembali kewajibannya. Dalam Penilaian calon nasabah pihak bank menggunakan prinsip 5C (character, capability, capital, colleteral, condition of economi). Hal demikian dilakukan mencegah timbulnya risiko pada pihak bank. Risiko menjadi bagian dari kehidupan manusia yang tidak dapat diketahui kapan terjadi, karena manusia selalu dihadapkan dengan berbagai macam risiko baik itu risiko besar maupun risiko kecil.

Menurut Kountur, (2004) risiko berhubungan dengan ketidakpastian dalam menjalankan kegiatan usahanya bank mempunyai tujuan untuk memperoleh pendapatan. Namun sering terjadi, perbankan selalu dihadapkan dengan risiko. Risiko kerugian pada perbankan dapat diakibatkan oleh dua hal. Yang pertama, risiko yang diakibatkan nasabah karena sengaja tidak mau membayar pembiayaannya padahal mampu dan kedua, risiko kerugian yang diakibatkan karena nasabah tidak sengaja yaitu akibat terjadinya musibah.

Sedangkan menurut Veithzal Rivai dan Arviyan Arifin (2010) meningkatnya produk pembiayaan dalam bank syariah akan mendatangkan risiko pembiayaan yang besar pula, hal ini dikarenakan pembiayaan produk investasi bank syariah termasuk dalam produk natural uncertainty contracts. Salah satunya produk pembiayaan yang paling banyak disalurkan seperti pembiayaan dalam prinsip mudharabah dan prinsip musyarakah. Pembiayaan yang disalurkan oleh bank kepada nasabah tidak terlepas oleh risiko, khususnya bank syariah yang manjadi tempat penelitian yaitu PT. Bank BRI syariah, Tbk.

Dalam hubungan uraian tersebut, akan dapat disajikan data pembiayaan mudharabah dan musyarakah yang disalurkan PT Bank BRI syariah, Tbk pada tahun 2012-2014 sebagai berikut: 


\section{PAY Jurnal Keuangan dan Perbankan. Vol. 3 No. 1, Juni 2021}

Tabel 1. Pembiayaan mudharabah dan musyarakah PT Bank BRI Syariah, Tbk pada tahun 2011-2013

\begin{tabular}{|c|c|c|c|}
\hline No & Tahun & $\begin{array}{c}\text { Pembiayaan } \\
\text { Mudharabah } \\
\text { (Rp) }\end{array}$ & $\begin{array}{c}\text { Pembiayaan } \\
\text { Musyarakah } \\
\text { (Rp) }\end{array}$ \\
\hline 1 & 2011 & 598.464 & 1.123 .372 \\
2 & 2012 & 859.252 & 1.737 .831 \\
3 & 2013 & 936.688 & 3.033 .517 \\
\hline
\end{tabular}

Sumber: www.idx.co.id

Berdasarkan tabel diatas dapat dilihat pembiayaan mudharabah dan musyarakah yang disalurkan PT. Bank BRI syariah, Tbk pada tahun 2011 sampai 2013 mengalami peningkatan. Dimana pembiayaan mudharabah yang disalurkan PT. Bank BRI syariah, Tbk pada tahun 2011 sebesar Rp. 598.464, 2012 sebesar Rp.859.252, dan 2013 sebesar Rp.936.688. Sedangkan pembiayaan musyarakah yang disalurkan PT. Bank BRI syariah, Tbk pada tahun 2011 sebesar Rp. 1.123.372, 2012 sebesar Rp. 1.737.831, dan 2013 sebesar Rp.3.033.517.

Adapun fenomena yang terjadi saat ini banyaknya nasabah yang membutuhkan pembiayaan dari bank maupun perusahaan yang menawarkan jasa pembiayaan baik yang berbasis konvensional maupun berbasis syariah. PT. Bank BRI syariah, Tbk salah satu bank yang berbasis syariah yang memberikan jasa pembiayaan kepada nasabah perorangan, Usaha Kecil dan Menegah (UKM), Korporasi dan Badan Usaha Milik Negara(BUMN). Dimana bentuk pembiayaan dalam perbankan syariah adalah pembiayaan mudharabah dan musyarakah. Nasabah melakukan pinjaman karena adanya kebutuhan ekonomi yang ingin dipenuhi.

Dari kegiatan pembiayaan, semakin banyak dana yang disalurkan maka potensi timbulnya risiko pun semakin besar karena pembiayaan merupakan salah satu aktivitas perbankan syariah yang memiliki risiko di sebabkan oleh adanya ketidak mampuan nasabah untuk melunasi kewajibannya atau memberikan bagi hasil kepada pihak bank.

Berdasarkan latar belakang tersebut, maka penulis akan melakukan penelitian dengan judul "Analisis Risiko Pembiayaan Mudharabah dan Musyarakah Perbankan Syariah Pada PT. Bank BRI Syariah, Tbk Yang Terdaftar Di Bursa Efek Indonesia (BEI)".

\section{B. Rumusan Masalah}

Berdasarkan latar belakang, maka penulis akan mengajukan rumusan masalah yaitu bagaimana tingkat risiko pembiayaan mudharabah dan musyarakah perbankan syariah pada PT. Bank BRI Syariah, Tbk yang terdaftar Di Bursa Efek Indonesia (BEI)?

\section{Tujuan Penelitian}

Adapun tujuan yang ingin dicapai dalam penelitian ini adalah untuk mengetahui tingkat risiko pembiayaan mudharabah dan musyarakah perbankan syariah pada PT. Bank BRI Syariah, Tbk yang terdaftar Di Bursa Efek Indonesia (BEI)?

\section{TINJAUAN PUSTAKA}

\section{A. Pengertian Pembiayaan}

Menurut Ahmad Sumiyanto (2008:165) pembiayaan adalah aktivitas menyalurkan dana yang terkumpul kepada anggota pengguna dana, memilih jenis usaha yang akan dibiayai agar diperoleh jenis usaha yang produktif, menguntungkan dan dikelola oleh anggota yang jujur dan bertanggung jawab.

Berdasarkan pengertian tersebut, dapat disimpulkan bahwa pembiayaan adalah pemberian dana oleh bank kepada nasabah untuk mendukung usaha yang telah direncanakan berdasarkan 


\section{PAY Jurnal Keuangan dan Perbankan. Vol. 3 No. 1, Juni 2021}

kesepakatan antara nasabah dengan bank yang mewajibkan para nasabah yang dibiayai dana tersebut mengembalikan tagihan/imbalan atau bagi hasil yang sudah disepakati dalam jangka waktu tertentu.

\section{B. Pembiayaan Mudharabah}

Menurut Sri Nurhayati dan Wasila (2013:128) mudharabah adalah sebagai akad kerjasama usaha antara dua pihak dimana pihak pertama (pemilik dana atau shahibul maal) menyediakan seluruh dana, sedangkan pihak kedua (pengelolah dana atau mudharib) bertindak selaku pengelolah, dan keuntungan dibagi diantara mereka sesuai kesepakatan sedangkan kerugian financial hanya ditanggung oleh pemilik dana. Kerugian akan ditanggung pemilik dana selama kerugian itu tidak diakibatkan oleh kelalaian pengelola dana, apabila kerugian yang terjadi diakibatkan oleh kelalaian pengelola dana maka kerugian ini akan ditanggung oleh pengelola dana.

Menurut PSAK No. 105 Mudharabah adalah akad kerjasama usaha antara dua pihak di mana pihak pertama (pemilik dana) menyediakan seluruh dana, sedangkan pihak kedua (pengelola dana) bertindak selaku pengelola, dan keuntungan dibagi di antara mereka sesuai kesepakatan sedangkan kerugian finansial hanya ditanggung oleh pemilik dana

\section{Pembiayaan Musyarakah}

Menurut Sri Nurhayati dan Wasilah (2008: 134) musyarakah adalah akad kerjasama antara dua pihak atau lebih untuk suatu usaha tertentu, dimana masing-masing pihak memberikan kontribusi dana dengan ketentuan bahwa keuntungan dibagi berdasarkan kesepakatan sedangkan kerugian berdasarkan porsi kontribusi dana.
Menurut PSAK No 106 paragraf 4 mendefinisikan Musyarakah adalah akad kerja sama antara dua pihak atau lebih untuk suatu usaha tertentu, di mana masing-masing pihak memberikan kontribusi dana dengan ketentuan bahwa keuntungan dibagi berdasarkan kesepakatan sedangkan kerugian berdasarkan porsi kontribusi dana.

\section{Pengertian Bank Syariah}

Menurut UU No.10 tahun 1998 tetang perbankan syariah disebutkan bahwa bank syariah adalah bank yang menjalankan kegiatan usahanya berdasarkan prinsip syariah dan menurut jenisnya terdiri atas bank umum syariah dan bank pembiayaan rakyat syariah.

Menurut UU No. 21 tahun 2008 mengenai perbankan syariah mengemukakan pengertian perbankan syariah dan bank syariah dimana perbankan syariah yaitu segala sesuatu yang mencakup bank syariah dan unit usaha syariah, mencankup kelembagaan, mencakup kegiatan usaha, serta tata cara dan proses di dalam melaksanakan kegiatan usahanya.

\section{METODE ANALISIS}

Metode analisis data yang digunakan dalam penelitian ini adalah sebagai berikut:

\section{Tingkat Risiko Pembiayaan}

Tingkat risiko pembiayaan merupakan risiko yang timbul karena bank tidak dapat memperoleh kembali dana yang telah disalurkan kepada nasabah melalui pembiayaan. Dikarenakan nasabah tidak membayar bagi hasil dan pokok pembiayaan yang telah diberikan oleh bank syariah sesuai dengan kesepakatan. Untuk menghitung tingkat risiko pembiayaan mudharabah dan musyarakah digunakan rasio Non Performing finance (NPF) sebagai berikut :

$$
\mathrm{NPF}=\frac{\text { Total Pembiayaan Bermasalah }}{\text { Total Pembiayaan }} \times 100
$$




\section{PAY Jurnal Keuangan dan Perbankan. Vol. 3 No. 1, Juni 2021}

Tujuan dari rasio NPF (Non Performing Finance) adalah untuk mengukur tingkat permasalah pembiayaan dihadapi oleh bank, semakin tinggi rasio NPF, menunjukkan kualitas pembiayaan bank syariah semakin buruk.

Tabel 2. Kriteria kesehatan non performing finance (NPF)

\begin{tabular}{|c|c|c|}
\hline No & Nilai NPF & Predikat \\
\hline 1 & NPF $>2 \%$ & Sehat \\
\hline 2 & $2 \% \leq \mathrm{NPF}<5 \%$ & Sehat \\
\hline 3 & $5 \% \leq \mathrm{NPF}<8 \%$ & Cukup Sehat \\
\hline 4 & $8 \% \leq \mathrm{NPF}<12 \%$ & Kurang Sehat \\
\hline 5 & $\mathrm{NPF} \geq 12 \%$ & Tidak Sehat \\
\hline
\end{tabular}

Sumber: SE BI No 9/24/Dpbs Tanggal 30 Oktober 2007

\section{HASIL PENELITIAN}

\section{A. Pembiayaan Mudhrabah dan Musyarakah}

Pembiayaan adalah penyediaan uang atau tagihan yang dipersamakan dengan itu berdasarkan persetujuan atau kesepakatan antara bank dengan pihak yang meminjam untuk mengembalikan uang atau tagihan tersebut setelah jangka waktu tertentu dengan imbalan bagi hasil.

Pembiayaan mudharabah adalah suatu akad kerja sama antara bank sebagai pemilik dana dan nasabah sebagai pihak yang dibiayai atau sebagai pihak yang mengelola dana dan keuntungan dari dana yang dikelola dibagi sesuai kesepakatan, sedangkan kerugian ditanggung oleh pemilik dana selama kerugian itu bukan kelalaian si pengelola tapi jika kerugian tersebut terjadi akibat kelalaian pengelola maka si pengelola yang akan menanggung kerugian/risikonya.

Pembiayaan musyarakah adalah akad kerja sama antara bank dengan nasabah dimana masing-masing pihak memiliki kotribusi dana terhadap suatu usaha dan keuntungan dibagi berdasarkan kesepakatan sedangkan kerugian berdasarkan porsi kontribusi dana.

Salah satu analisis yang terpenting dilakukan oleh lembaga Bank Syariah adalah Analisis Risiko Pembiayaan Mudharabah dan Pembiayaan Musyarakah. Hal ini dilakukan untuk mengetahui apakah pembiayaan yang disalurkan bank kepada nasabah bermasalah/berisiko atau tidak.

PT. Bank BRI Syariah, Tbk menggolongkan kualitas aset menjadi lancar, dalam perhatian khusus, kurang lancar, diragukan dan macet. Berdasarkan peraturan bank Indonesia yang termasuk dalam golongan aset bermasalah meliputi kurang lancar, diragukan dan macet.

Berikut ini penggolongan dan kriteria pembiayaan bermasalah Menurut Kasmir (2008:131):

1. Kurang lancer

Pembiayaan yang digolongkan ke dalam pembiayaan kurang lancar apabila memenuhi kriteria berikut ini:

a. Terdapata tunggakan angsuran pokok dan/atau bunga telah melampui 90 hari

b. Sering terjadi cerukan

c. Frekuensi mutasi rekening relative rendah

d. Terjadi pelanggaran terhadap kontrak yang diperjanjikan lebih dari 90 hari

e. Terdapat indikasi masalah keuangan yang dihadapi debitur

f. Dokumentasi pinjaman yang lemah

2. Diragukan

Pembiayaan yang digolongkan ke dalam pembiayaan yang diragukan apabila memenuhi kriteria berikut ini:

a. Terdapat tunggakan angsuran pokok dan/atau bunga yang telah melampaui 180 hari 


\section{PAY Jurnal Keuangan dan Perbankan. Vol. 3 No. 1, Juni 2021}

b. Terjadi cerukan yang bersifat permanen

c. Terjadi wanprestasi lebih dari 180 hari

d. Terjadi kapitalisasi bunga

e. Dokumentasi hukum yang lemah baik untuk perjanjian pembiayaan maupun peningkatan jaminan

3. Macet

Pembiayaan yang digolongkan ke dalam pembiayaan macet apabila memenuhi kriteria berikut ini:

a. Prospek usaha

1) Kelangsungan usaha sangat diragukan, industry mengalami penurunan dan sulit untuk pulih kembali

2) Kemingkinan besar kegiatan usaha akan berhenti

3) Kehilangan pasar sejalan dengan kondisi perekonomian yang menurun

4) Manajemen sangat lemah

5) Perusahaan afiliasi sangat merugikan debitur

6) Terjadi pemogokan tenaga kerja yang sulit diatasi

b. Kondisi keuangan

1) Mengalami kerugian yang besar

2) Debitur tidak mampu memenuhi seluruh kewajiban dan kegiatan usaha

3) Usaha debitur tidak dapat dipertahankan

4) Rasio utang terhadap modal sangat tinggi

5) Kesulitas likuiditas

6) Analisa arus kas menunjukan bahwa kreditur tidak mampu menutup biaya produksi

7) Kegiatan usaha terancam karena fluktuasi nilai tukar valuta asing dan suku bunga

8) Pinjaman baru digunakan untuk menutup kerugian operasional c. Kemampuan membayar

1) Terdapat tunggakan pokon dan/atau bunga yang telah melampaui 270 hari

2) Dokumentasi kredit dan/atau pengikatan agunan tidak ada

Adapun data pembiayaan bermasalah pembiayaan mudharabah dan musyarakah PT. Bank BRI Syariah, Tbk selama tahun 2015 sampai 2019 adalah sebagai berikut:

Tabel 3. Pembiayaan Bermasalah Mudharabah

\begin{tabular}{|c|c|c|c|c|}
\hline \multirow{2}{*}{ Tahun } & \multicolumn{3}{|c|}{$\begin{array}{c}\text { Pembiayaan Mudharabah } \\
\text { Bermasalah }\end{array}$} & \multirow{2}{*}{ Total } \\
\cline { 2 - 4 } & $\begin{array}{c}\text { Kurang } \\
\text { Lancar } \\
\text { (Rp) }\end{array}$ & $\begin{array}{c}\text { Diragukan } \\
(\mathbf{R p})\end{array}$ & $\begin{array}{c}\text { Macet } \\
(\mathbf{R p})\end{array}$ & \\
\hline 2015 & 567 & 505 & 3.144 & $\mathbf{4 . 2 1 6}$ \\
\hline 2016 & 14 & 1.410 & 55 & $\mathbf{1 . 4 7 9}$ \\
\hline 2017 & 1.863 & 2.063 & 6.871 & $\mathbf{1 0 . 7 9 7}$ \\
\hline 2018 & 395 & 2.840 & 3.295 & $\mathbf{6 . 5 3 0}$ \\
\hline 2019 & 268 & 1.735 & 1.007 & $\mathbf{3 . 0 1 0}$ \\
\hline
\end{tabular}

Sumber: Data Diolah www.idx.co.id (PT. Bank BRI Syariah,Tbk), 2020

Berdasarkan tabel tersebut, dapat dijelaskan bahwa pembiayaan mudharabah bermasalah PT. Bank BRI Syariah Tbk dari tahun 2015 sampai tahun 2019, dimana pada tahun 2017 pembiayaan mudharabah mengalami pembiayaan bermasalah paling tinggi yaitu Rp.10.797 dibandingkan tahun yang lain. Hal ini disebabkan karena banyak nasabah tidak membayar bagi hasil dan pokok pembiayaan yang telah diberikan oleh bank syariah sesuai kesepakatan sejak awal.

Tabel 4. Pembiayaan Bermasalah musyarakah

\begin{tabular}{|c|c|c|c|c|}
\hline \multirow[b]{2}{*}{ Tahun } & \multicolumn{3}{|c|}{ Pembiayaan Musyarakah Bermasalah } & \multirow[b]{2}{*}{$\begin{array}{l}\text { Total } \\
\text { (Rp) }\end{array}$} \\
\hline & $\begin{array}{c}\text { Kurang } \\
\text { Lancar } \\
\text { (Rp) }\end{array}$ & $\begin{array}{c}\text { Diragukan } \\
\text { (Rp) }\end{array}$ & $\begin{array}{c}\text { Macet } \\
\text { (Rp) }\end{array}$ & \\
\hline 2015 & 86.178 & 14.117 & 194.097 & 294.392 \\
\hline 2016 & 92.258 & 12.056 & 163.726 & 268.040 \\
\hline 2017 & 140.292 & 13.424 & 213.939 & 367.655 \\
\hline 2018 & 164.788 & 145.995 & 274.243 & 585.026 \\
\hline 2019 & 106.843 & 10.026 & 387.356 & 408.066 \\
\hline
\end{tabular}

Sumber: Data Diolah www.idx.co.id (PT. Bank BRI Syariah, Tbk), 2020

Berdasarkan tabel tersebut, dapat dijelaskan bahwa pembiayaan musyarakah bermasalah PT. Bank BRI 


\section{PAY Jurnal Keuangan dan Perbankan. Vol. 3 No. 1, Juni 2021}

Syariah, Tbk dari tahun 2015 sampai tahun 2019, dimana pada tahun 2018 pembiayaan musyarakah mengalami pembiayaan bermasalah paling tinggi yaitu sebesar Rp.585.026 dibandingkan tahun yang lain. Hal ini disebabkan karena banyak nasabah tidak membayar bagi hasil dan pokok pembiayaan yang telah diberikan oleh bank syariah sesuai kesepakatan sejak awal.

Tabel 5. Total Pembiayaan Mudharabah dan Musyarakah

\begin{tabular}{|c|c|c|c|}
\hline No & Tahun & $\begin{array}{c}\text { Total } \\
\text { Pembiayaan } \\
\text { Mudharabah } \\
\text { (RP) }\end{array}$ & $\begin{array}{c}\text { Total } \\
\text { Pembiayaan } \\
\text { Musyarakah } \\
(\mathbf{R P})\end{array}$ \\
\hline 1 & 2015 & 1.106 .566 & 4.962 .346 \\
\hline 2 & 2016 & 1.271 .485 & 5.185 .890 \\
\hline 3 & 2017 & 840.974 & 5.447 .998 \\
\hline 4 & 2018 & 475.300 & 7.406 .955 \\
\hline 5 & 2019 & 407.246 & 11.019 .873 \\
\hline
\end{tabular}

Sumber: Data Diolah www.idx.co.id (PT. Bank BRI Syariah Tbk), 2020

Berdasarkan tabel tersebut, dapat dijelaskan bahwa Total pembiayaan Mudharabah dan Musyarakah yang disalurkan PT. Bank BRI Syariah Tbk kepada nasabah dari tahun 2015 sampai tahun 2019, dimana pembiayaan mudharabah 5 tahun berturut-turut mengalami penurunan. Hal yang menyebabkan pembiayaan mudharabah menurun setiap tahunya adanya kekhawatiran yang berlebihan oleh pihak bank terhadap kinerja mitra usahanya atau terhadap nasib dananya dikarenakan pihak mudharib tidak bisa memberikan kepastian pendapatan baik dari segi jumlah maupun waktunya menyebabkan pihak investor menjadi ragu untuk menyalurkan pembiayaan mudharabah. Juga karena termasuk mengandung resiko yang tinggi dalam hal nasabah menggunakan dana menyimpang dari kontrak, Lalai dan kesalahan yang disengaja, dan penyembunyian keuntungan oleh nasabah yang tidak jujur.

Sedangkan pembiayaan musyarakah 5 tahun berturut-turut mengalami peningkatan. Hal ini disebabkan karena pihak bank PT. Bank BRI Syariah Tbk maupun nasabah telah terjadi kesepakatan aturan dan rasa kepercayaan antara kedua belah pihak dalam pengelolaan dana usaha.

\section{B. Non Performing Financing (NPF)}

Rasio NPF adalah rasio yang digunakan untuk mengukur risiko kegagalan dari pembiayaan, dimana NPF adalah rasio antara pembiayaan bermasalah (yang masuk dalam kriteria pembiayaan kurang lancar, diragukan, dan macet) dengan total pembiayaan yang disalurkan.

Tabel 6. Daftar tingkat risiko pembiayaan mudharabah dan musyarakah PT. Bank BRI Syariah, Tbk.

\begin{tabular}{|c|c|c|c|c|}
\hline \multirow{2}{*}{ Tahun } & \multicolumn{2}{|c|}{ Pembiayaan Mudharabah } & \multicolumn{2}{c|}{ Pembiayaan Musyarakah } \\
\cline { 2 - 5 } & $\begin{array}{c}\text { Pembiayaan } \\
\text { Bermasalah } \\
(\mathbf{R p})\end{array}$ & $\begin{array}{c}\text { Total } \\
\text { Pembiayaan } \\
(\mathbf{R p})\end{array}$ & $\begin{array}{c}\text { Pembiayaan } \\
\text { Bermasalah } \\
(\mathbf{R p})\end{array}$ & $\begin{array}{c}\text { Total } \\
\text { Pembiayaan } \\
(\mathbf{R p})\end{array}$ \\
\hline 2015 & 4.216 & 1.106 .566 & 294.392 & 4.962 .346 \\
\hline 2016 & 1.479 & 1.271 .485 & 268.040 & 5.185 .890 \\
\hline 2017 & 10.797 & 840.974 & 367.655 & 5.447 .998 \\
\hline 2018 & 6.530 & 475.300 & 585.026 & 7.406 .955 \\
\hline 2019 & 3.010 & 407.246 & 408.066 & 11.019 .873 \\
\hline
\end{tabular}

Sumber: Data Diolah,2020

\section{Pembiayaan mudharabah}

Tahun 2015:

$$
\begin{aligned}
\text { NFP Mudharabah } & =\frac{\text { Pembiayaan Bermasalah }}{\text { Total Pembiayaan }} \times 100 \% \\
& =\frac{4.216}{1.106 .566} \times 100 \% \\
& =0,39 \%
\end{aligned}
$$

Tahun 2016:

$$
\begin{aligned}
\text { NFP Mudharabah } & =\frac{\text { Pembiayaan Bermasalah }}{\text { Total Pembiayaan }} \times 100 \% \\
& =\frac{1.479}{1.271 .485} \times 100 \% \\
& =0,12 \%
\end{aligned}
$$

Tahun 2017:

$$
\begin{aligned}
\text { NFP Mudharabah } & =\frac{\text { Pembiayaan Bermasalah }}{\text { Total Pembiayaan }} \times 100 \% \\
& =\frac{10.797}{840.974} \times 100 \% \\
& =1.29 \%
\end{aligned}
$$

Tahun 2018:

$$
\begin{aligned}
\text { NFP Mudharabah } & =\frac{\text { Pembiayaan Bermasalah }}{\text { Total Pembiayaan }} \times 100 \% \\
& =\frac{6.530}{475.300} \times 100 \% \\
& =1.38 \%
\end{aligned}
$$




\section{PAY Jurnal Keuangan dan Perbankan. Vol. 3 No. 1, Juni 2021}

Tahun 2019:

NFP Mudharabah $=\frac{\text { Pembiayaan Bermasalah }}{\text { Total Pembiayaan }} \times 100 \%$

$$
\begin{aligned}
& =\frac{3.010}{407.246} \times 100 \% \\
& =0,74 \%
\end{aligned}
$$

\section{Pembiayaan musyarakah}

Tahun 2015:

$$
\begin{aligned}
\text { NFP Musyarakah } & =\frac{\text { Pembiayaan Bermasalah }}{\text { Total Pembiayaan }} \times 100 \% \\
& =\frac{294.392}{4.962 .346} \times 100 \% \\
& =5.94 \%
\end{aligned}
$$

Tahun 2016:

NFP Musyarakah $=\frac{\text { Pembiayaan Bermasalah }}{\text { Total Pembiayaan }} \times 100 \%$

$$
\begin{aligned}
& =\frac{268.040}{5.185 .890} \times 100 \% \\
& =5.17 \%
\end{aligned}
$$

Tahun 2017:

NFP Musyarakah $=\frac{\text { Pembiayaan Bermasalah }}{\text { Total Pembiayaan }} \times 100 \%$

$$
\begin{aligned}
& =\frac{367.655}{5.447 .998} \times 100 \% \\
& =6.75 \%
\end{aligned}
$$

Tahun 2018:

NFP Musyarakah $=\frac{\text { Pembiayaan Bermasalah }}{\text { Total Pembiayaan }} \times 100 \%$

$$
\begin{aligned}
& =\frac{585.026}{7.406 .955} \times 100 \% \\
& =7.89 \%
\end{aligned}
$$

Tahun 2019:

$$
\begin{aligned}
\text { NFP Musyarakah } & =\frac{\text { Pembiayaan Bermasalah }}{\text { Total Pembiayaan }} \times 100 \% \\
& =\frac{408.066}{11.019 .873} \times 100 \% \\
& =3.71 \%
\end{aligned}
$$

Berdasarkan hasil perhitungan Non Performing Financing (NPF) maka dapat disimpulkan tabel berikut:

Tabel 7. Hasil Tingkat Risiko Pembiayaan (NPF) mudharabah dan Musyarakah PT. Bank BRI Syariah, Tbk

\begin{tabular}{|c|c|c|}
\hline Tahun & $\begin{array}{c}\text { NPF } \\
\text { Pembiayaan } \\
\text { Mudharabah } \\
(\boldsymbol{\%})\end{array}$ & $\begin{array}{c}\text { NPF } \\
\text { Pembiayaan } \\
\text { Musyarakah } \\
(\boldsymbol{\%})\end{array}$ \\
\hline 2015 & $0,39 \%$ & $5.94 \%$ \\
\hline 2016 & $0,12 \%$ & $5.17 \%$ \\
\hline 2017 & $1.29 \%$ & $6.75 \%$ \\
\hline 2018 & $1.38 \%$ & $7.89 \%$ \\
\hline 2019 & $0,74 \%$ & $3.71 \%$ \\
\hline
\end{tabular}

Sumber: Analisis Data Diolah, 2020
Dari hasil perhitungan tingkat risiko pembiayaan (NPF) mudharabah dan musyarakah tahun 2015 sampai 2019 yang telah dikemukakan pada tabel tersebut, dapat dijelaskan sebagai berikut:

a. Tingkat risiko pembiayaan mudharabah

Tingkat risiko pembiayaan (NPF) mudharabah PT. Bank BRI Syariah, Tbk pada tahun 2015 sampai 2019. Dapat dijelaskan bahwa pada tahun 2015 sebesar 0,39\%, 2016 sebesar 0,12\%, 2017 sebesar 1,29\%, 2018 sebesar 1,38\%, dan 2019 sebesar $0,74 \%$ ini berarti bahwa tingkat risiko pembiayaan (NPF) mudharabah PT. Bank BRI Syariah Tbk pada tahun 2015 sampai 2019 berada di peringkat pertama $<2 \%$ atau sehat, yang menunjukkan bahwa kualitas pembiayaan PT. Bank BRI Syariah, Tbk dalam kondisi yang baik atau tidak berisiko. Hal ini disebabkan karena manajemen PT. Bank BRI Syariah Tbk terus berupaya melakukan peningkatan kualitas pembiayaan dengan melakukan monitoring dan pihak bank semakin berhati-hati dalam memilih nasabah untuk menyalurkan pembiayaanya. Sedangkan tingkat risiko pembiayaan (NPF) mudharabah paling tinggi dari tahun 2015 sampai 2015 terjadi pada tahun 2018 sebesar $1.38 \%$. Hal ini terjadi dikarenakan besarnya jumlah pembiayaan mudharabah yang disalurkan, sehingga menimbulkan tingginya risiko pembiayaan yang terjadi.

b. Tingkat risiko pembiayaan musyarakah

Tingkat risiko pembiayaan (NPF) musyarakah PT. Bank BRI Syariah, Tbk pada tahun 2015 sampai 2019. Dapat dijelaskan bahwa pada tahun 2015 sebesar 5,94\%, 2016 sebesar 


\section{PAY Jurnal Keuangan dan Perbankan. Vol. 3 No. 1, Juni 2021}

$5,17 \%, 2017$ sebesar $6,75 \%, 2018$ sebesar $7,89 \%$ ini berarti pembiayaan musyarakah pada tahun 2015 sampai 2018 berada di peringkat ketiga $5 \% \leq \mathrm{NPF}<8 \%$ atau cukup sehat, ini berarti bahwa kualitas pembiayaan musyarakah PT. Bank BRI Syariah, Tbk tidak terlalu baik atau berada dalam kondisi berisiko. Hal ini disebabkan karena terdapat adanya nasabah tidak lancar dalam pengembalian atas bagi hasil. Pada tahun 2019 tingkat risiko pembiayaan (NPF) musyarakah sebesar $3.71 \%$ ini berarti berada diperingkat kedua $2 \% \leq \mathrm{NPF}<5 \%$ atau sehat yang menunjukkan bahwa kualitas pembiayaan PT. Bank BRI Syariah, Tbk dalam kondisi yang baik atau tidak berisiko. Jadi pada tahun 2019 tingkat pembiayaan musyarakah PT. Bank BRI Syariah, Tbk dalam kondisi tidak berisiko dibandingkan pada tahun 2015, 2016, 2017, dan 2018 tingkat pembiayaan musyarakah dalam kondisi berisiko. Hal yang menyebabkan tingkat pembiayaan musyarakah pada tahun 2019 tidak berisiko adalah jumlah pembiayaan yang disalurkan PT. Bank BRI Syariah, Tbk lebih kecil dari pada tahun 2015, 2016, 2017, dan 2018. Sedangkan tingkat risiko pembiayaan (NPF) musyarakah paling tinggi dari tahun 2015 sampai 2015 terjadi pada tahun 2018 sebesar $7.89 \%$. Hal ini terjadi dikarenakan besarnya jumlah pembiayaan musyarakah yang disalurkan PT. Bank BRI Syariah, Tbk, sehingga menimbulkan tingginya risiko pembiayaan yang terjadi.

\section{KESIMPULAN}

Berdasarkan hasil penelitian dan pembahasan maka dapat disimpulkan sebagai berikut:
1. Pembiayaan

bermasalah mudharabah PT. Bank BRI Syariah, Tbk paling tinggi terjadi pada tahun 2017 yaitu sebesar Rp.10.797. sedangkan, Pembiayaan bermasalah musyarakah paling tinggi PT. Bank BRI Syariah, Tbk terjadi pada tahun 2018 yaitu sebesar Rp.585.026.

2. Tingkat risiko pembiayaan(NPF) mudharabah PT. Bank BRI Syariah, Tbk dari tahun 2015 sampai 2019 berada dalam kondisi yang baik atau tidak berisiko dimana pada tahun 2015 sebesar 0,39\%, 2016 sebesar 0,12\%, 2017 sebesar 1,29\%, 2018 sebesar 1,38\%, dan 2019 sebesar $0,74 \%$ ini berarti bahwa tingkat risiko pembiayaan (NPF) mudharabah PT. Bank BRI Syariah,Tbk berada di peringkat pertama $<2 \%$. Dan tingkat risiko pembiayaan mudharabah paling tinggi terjadi pada tahun 2018 sebesar $1,38 \%$.

3. Tingkat risiko pembiayaan (NPF) musyarakah PT. Bank BRI Syariah,Tbk pada tahun 2015 sampai 2018 berada dalam kondisi berisiko dimana pada tahun 2015 sebesar 5,94\%, 2016 sebesar 5,17\%, 2017 sebesar $6,75 \%, 2018$ sebesar 7,89\% ini berarti berada di peringkat ketiga $5 \% \leq \mathrm{NPF}<8 \%$. Dan pada tahun 2019 tingkat risiko pembiayaan(NPF) musyarakah berada dalam kondisi yang baik dimana pada tahun 2019 sebesar $3.71 \%$ ini berarti berada diperingkat kedua $2 \% \leq \mathrm{NPF}<5 \%$. Dan tingkat risiko pembiayaan musyarakah paling tinggi terjadi pada tahun 2018 sebesar 7,89\%.

\section{SARAN}

1. Pihak bank dalam melakukan pembiayaan harus perlu teliti dan selektif dalam memilih nasabah yang akan berikan pembiayaan agar tidak terjadi pembiayaan yang 


\section{PAY Jurnal Keuangan dan Perbankan. Vol. 3 No. 1, Juni 2021}

menyimpang sehingga menimbulkan risiko kepada pembiayaan dan menimbulkan berkurangnya pendapatan pada bank.

2. Pihak Bank PT. Bank BRI Syariah, Tbk perlu membuat aturan jelas mengenai sanksi yang diberikan kepada nasabah apabila menunggak dalam pengembalian bagi hasil pembiayaan yang diberikan.

\section{DAFTAR PUSTAKA}

Anonim, Bank Indonesia, 2008, Undang-Undang Tentang Bank Syariah. 2009, Ikatan Akuntansi Indonesia, , Pernyataan Standar Akuntansi Syariah.

Bank Indonesia (2005). Booklet Perbankan Indonesia 2007, Jakarta: Direktorat Perizinan dan Informasi Perbankan Bank Indonesia.

Fransiska, Fina Dita, 2018. "Analisis Risiko Kerugian Bank Dalam Pembiayaan Pegawai Tanpa Agunan". Jurnal, Fakultas Ekonomi Dan Bisnis Islam, Universitas Islam Negeri Raden Intan Lampung

Hanafi, 2006. Manaemen Risiko Operasional. Jakarta: Pendidikan dan pembinaan manajemen.

Kountur, Ronny, 2004. Manajemen Risiko Operasional: Memahami Cara Mengelola Risiko Operasional Perusahaan. Jakarta: PPM

Kasmir, 2008. Dasar-Dasar Perbankan. Jakarta: PT Raja Grafindo Persada.

Marhaeni, Syamsu Alam, \& Muh. Alam Nasyrah Hanafi. 2020. Analisis Kinerja Keuangan dengan Menggunakan Rasio Profitabilitas pada PT. Indofood Sukses Makmur Tbk. yang Terdaftar di Bursa Efek Indonesia (BEI). PAY Jurnal Keuangan dan Perbankan, Vol. 2 No. 2, 69-74. http://ejournals.umma.ac.id/ind ex.php/pay/article/view/753.

M. Yusuf Dan Wiroso, 2011. Bisnis Syariah. Jakarta: Mitra Wacana Media.

Nurhayati Sri, Wasila, 2013. Akuntansi Syariah di Indonesia Edisi 3, Jakarta: Salemba Empat.

Pransisca, Novelia Deby, 2014. "Analisis Risiko Pembiayaan Mudharabah, Risiko Musyarakah dan Profitabilitas Bank Syariah PT. Bank Syariah Mandiri Tbk". Fakultas Ekonomi, Universitas Negeri Yogyakarta.

Suryanti S, 2015. "Analisis Risiko Pembiayaan Terhadap Usaha Perbankan Syariah", Jurnal, Sekolah Tinggi Ilmu Manajemen, Yayasan Perguruan Islam Maros

Sri Nurhayati dan Wasila, 2008. Akuntansi Syariah di Indonesia. Jakarta: Salemba Empat

Sumiyanto, Ahmad, 2008. BMT Мепији Koperasi Modern. Yogyakarta: Ises Publihsing.

Sugiyono, (2017). Metode penelitian kuantitatif, kualitatif, dan $R \& D$.Bandung: Alfabeta, CV.

Surat Edaran Bank Indonesia No. 9/24/Dpbs Tanggal 30 Oktober 2007.

Veithzal Rivai dan Arviyan Arifin, 2010. Islamic Banking: Sebuah Teori Konsep dan Aplikasi. Jakarta: Bumi Aksara.

Pasal 1 ayat (2) peraturan Bank Indonesia No.5/8/PBI/2003.

www.idx.co.id

www.brisyariah.coid. 